\title{
PERAN MOTIVASI KERJA DALAM MENJEMBATANI ANTARA KARAKTERISTIK PEKERJAAN DAN KOMPENSASI TERHADAP KINERJA PEGAWAI NON ASN DI KECAMATAN PAKIS AJI, JEPARA
}

\author{
Indra Hary Tri Setyawan ${ }^{1)}$;Pahlawansyah Harahap \\ indraharytris@gmail.com ${ }^{11}$; pahlawan@usm.ac.id ${ }^{2)}$
}

\section{Program Studi Magister Manajemen,Universitas Semarang,Semarang,Indonesia}

\begin{tabular}{l} 
Info Artikel \\
\hline Sejarah Artikel: \\
Diterima;03-02-2019 \\
Disetujui;12-03-2019 \\
Dipublikasikan ; 07- \\
04-2019 \\
\hline Kata kunci \\
karakteristik \\
pekerjaan, \\
kompensasi, \\
motivasi kerja, \\
kinerja pegawai
\end{tabular}

Abstrak

Tujuan dalam penelitian ini adalah untuk menganalisa pengaruh karakteristik pekerjaan dan kompensasi terhadap motivasi kerja, serta menganalisa pengaruh karakteristik pekerjaan, kompensasi dan motivasi kerja terhadap kinerja pegawai.

Populasi dalam penelitian ini adalah seluruh pegawai kelurahan non ASN di Kecamatan Pakis Aji, Jepara yang berjumlah 101 dengan metode penentuan sampel yang dipergunakan adalah sensus sampling, yang artinya keseluruhan jumlah populasi dijadikan sampel penelitian. Alat analisis menggunakan SEM (struktur equitions modeling)

Hasil penelitian membuktikan bahwa karakteristik pekerjaan dan kompensasi berpengaruh signifikan terhadap motivasi kerja. Karakteristik pekerjaan dan kompensasi tidak berpengaruh terhadap kinerja pegawai. Motivasi kerja berpengaruh signifikan terhadap kinerja pegawai.

\section{THE ROLE OF WORK MOTIVATION IN BRIDGING BETWEEN WORK AND COMPENSATION CHARACTERISTICS OF NON ASN EMPLOYEE PERFORMANCE IN KECAMATAN PAKIS AJI, JEPARA}

\section{Abstract}

The purpose of this study is to analyze the effect of job characteristics and compensation on work motivation, and analyze the influence of job characteristics, compensation and work motivation on employee performance.

The population in this study were all employees of non-ASN urban villages in Pakis Aji Subdistrict, Jepara, which numbered 101 with the method of determining the sample used was census sampling, which means that the total population was used as the research sample. Analysis tools using SEM (structural modeling equations)

The results of the study prove that job characteristics and compensation have a significant effect on work motivation. Job characteristics and compensation do not affect employee performance. Work motivation has a significant effect on employee performance.

\footnotetext{
Alamat korespondensi :

Magister Manajemen, Universitas Semarang,jl Soekarno-Hatta,Semarang

E-mail: indraharytris@gmail.com
} 


\section{PENDAHULUAN}

Dalam perkembangan perusahaan, manajemen sumber daya manusia memiliki peran yang sangat penting. Manajemen sumber daya manusia menjadi faktor yang tidak bisa ditinggalkan dalam perusahaan guna mencapai tujuanya. Manajemen sumber daya manusia mengatur segala aspek yang berhubungan dengan perusahaan mulai dari perusahaan itu sendiri hingga pada karyawan (Zukrufillah, 2018).

Kinerja karyawan menjadi tolak ukur untuk mencapai tujuan perusahaan. Selain sarana dan prasarana karyawan merupakan salah satu faktor keberhasilan dalam perusahaan. Karyawan yang memiliki kinerja yang baik maka akan meningkatkan produktivitas yang ada dalam perusahaan. Kinerja karyawan sering diartikan sebagai pencapaian tugas, dimana karyawan dalam bekerja harus sesuai dengan program kerja organisasi untuk menunjukkan tingkat kinerja organisasi dalam mencapai visi, misi, dan tujuan organisasi. Menurut Dharma, (2018) Kinerja karyawan adalah tingkat terhadapnya para karyawan mencapai persyaratan pekerjaan Penilaian kinerja pada umumnya mencakup baik aspek kualitatif maupun kuntitatif dari kinerja pelaksanaan pekerjaan.

Tabel 1 Penilaian kinerja pegawai Non ASN Periode Tahun 2017

\begin{tabular}{|c|l|c|c|}
\hline No. & \multicolumn{1}{|c|}{ Penilaian } & Target & $\begin{array}{c}\text { Rata-Rata } \\
\text { Realisasi }\end{array}$ \\
\hline 1. & Kualitas hasil kerja & $80 \%$ & $69 \%$ \\
\hline 2. & $\begin{array}{l}\text { Pelaksanaan pekerjaan } \\
\text { sesuai tugas pokok dan } \\
\text { fungsi }\end{array}$ & $80 \%$ & $75 \%$ \\
\hline 3. & $\begin{array}{l}\text { Tanggung jawab } \\
\text { penyelesaian tugas }\end{array}$ & $85 \%$ & $80 \%$ \\
\hline 4. & $\begin{array}{l}\text { Proses administrasi } \\
\text { pelayanan }\end{array}$ & $85 \%$ & $81 \%$ \\
\hline 5. & Efektivitas kerja & $83 \%$ \\
\hline
\end{tabular}

Sumber : Kecamatan Pakis Aji, Jepara, 2018

Berdasarkan tabel 1.1 dapat dilihat bahwa penilaian kinerja pegawai tidak mencapai target sesuai kebijakan yang diberikan pemerintah daerah, kejadian ini dikarenakan sikap dan perilaku pegawai non ASN dalam menjalankan pekerjaan kurang optimal. Kendala utama seseorang dalam melaksanakan pekerjaan berhubungan erat dengan karakteristik seseorang dari segi pekerjaan, selain itu faktor kompensasi juga menjadi tuntutan kebutuhan mereka. 
Tabel 2. Research Gap

\begin{tabular}{|l|l|l|}
\hline Issue & Peneliti & Kesenjangan Hasil \\
\hline $\begin{array}{l}\text { Pengaruh } \\
\text { karakteristik } \\
\text { pekerjaan terhadap } \\
\text { kinerja pegawai }\end{array}$ & Hermawan, (2012) & $\begin{array}{l}\text { Karakteristik pekerjaan berpengaruh } \\
\text { signifikan terhadap kinerja pegawai }\end{array}$ \\
\cline { 2 - 3 } & Dharma, (2018) & $\begin{array}{l}\text { Karakteristik pekerjaan tidak } \\
\text { berpengaruh terhadap kinerja } \\
\text { pegawai }\end{array}$ \\
\hline $\begin{array}{l}\text { Pengaruh } \\
\text { kompensasi } \\
\text { terhadap kinerja } \\
\text { pegawai }\end{array}$ & Santoso, (2017) & $\begin{array}{l}\text { Kompensasi berpengaruh signifikan } \\
\text { terhadap kinerja pegawai }\end{array}$ \\
\cline { 2 - 3 } & Zukrufillah, (2018) & $\begin{array}{l}\text { Kompensasi tidak berpengaruh } \\
\text { terhadap kinerja pegawai }\end{array}$ \\
\hline
\end{tabular}

Sumber : ringkasan hasil penelitian terdahulu, 2018

Berdasarkan tabel 1.2 dapat dilihat bahwa terjadi permasalahan penelitian yaitu kesenjangan hasil penelitian antara variabel karakteristik pekerjaan dan kompensasi terhadap kinerja pegawai, oleh karena itu penelitian ini menambahkan variabel intervening motivasi kerja. Dalam rangka meningkatkan kinerja pegawai, motivasi sangat diperlukan untuk mendorong individu atau pegawai dalam mencapai tujuan, meningkatkan semangat kerja dan memiliki rasa tanggung jawab yang tinggi. Hal ini didukung dengan penelitian yang dilakukan Santoso, (2017) dan Dharma, (2018) bahwa motivasi kerja berpengaruh signifikan terhadap kinerja pegawai.

\section{Perumusan Masalah Penelitian}

Fenomena dalam penelitian ini adalah kurang optimalnya kinerja pegawai di Kecamatan Pakis Aji, Kabupaten Jepara dan permasalahan penelitiannya adalah adanya kesenjangan hasil penelitian antara variabel karakteristik pekerjaan dan kompensasi terhadap kinerja pegawai, oleh karena itu penelitian ini menambahkan variabel intervening motivasi kerja. sehingga dapat dirumuskan masalah penelitian yaitu bagaimana meningkatkan kinerja pegawai melalui motivasi kerja sebagai variabel intervening.

Berdasarka uraian rumusan masalah diatas, maka dapat diajukan pertanyaan penelitian sebagai berikut :

1. Apakah karakteristik pekerjaan berpengaruh terhadap motivasi kerja ?

2. Apakah kompensasi berpengaruh terhadap motivasi kerja?

3. Apakah karakteristik pekerjaan berpengaruh terhadap kinerja pegawai?

4. Apakah kompensasi berpengaruh terhadap kinerja pegawai?

5. Apakah motivasi kerja berpengaruh terhadap kinerja pegawai? 


\section{Tujuan Penelitian}

Penelitian ini memiliki tujuan penelitian yaitu :

1. Menganalisa pengaruh karakteristik pekerjaan terhadap motivasi kerja

2. Menganalisa pengaruh kompensasi terhadap motivasi kerja

3. Menganalisa pengaruh karakteristik pekerjaan terhadap kinerja pegawai

4. Menganalisa pengaruh kompensasi terhadap kinerja pegawai

5. Menganalisa pengaruh motivasi kerja terhadap kinerja pegawai

\section{TELAAH PUSTAKA}

\section{Kinerja Pegawai}

Kinerja pegawai adalah suatu hasil kerja yang dicapai seseorang dalam melaksanakan tugas-tugas yang dibebankan kepadanya yang didasarkan atas kecakapan, pengalaman dan kesungguhan serta waktu (Hasibuan, 2009). Sedangkan menurut Khoirul umam (2013) kinerja adalah semua tindakan atau prilaku yang dikontrol oleh individu dan memberikan kontribusi bagi pencapaian tujuan-tujuan bagi organisasi.

\section{Motivasi Kerja}

Motivasi adalah serangkaian sikap dan nilai-nilai yang mempengaruhi individu untuk mencapai hal yang spesifik sesuai dengan tujuan individu (Rivai dan Sagala, 2009). Motivasi kerja didefinisikan sebagai suatu proses yang dengannya perilaku kerja seseorang diberi energi, diarahkan, dan dipertahankan di dalam kehidupan kerja dan organisasai (Steer dan Proter, dalam Leonard . 1999).

\section{Karakteristik Pekerjaan}

Karakteristik pekerjaan adalah keanekaragaman tugas, identitas tugas, keberartian tugas, otonomi, dan umpan balik (Panggabean, 2004). Sedangkan menurut Sugito dan Nurjannah (2004), karakteristik pekerjaan merupakan sifat tugas yang meliputi besarnya tanggung-jawab dan macam-macam tugas yang diemban oleh tenaga kerja.

\section{Kompensasi}

Kompensasi adalah apa yang seorang pekerja terima sebagai balasan dari pekerjaan yang diberikannya (Hasibuan, 2009). Kompensasi juga merupakan faktor yang dapat mempengaruhi prestasi kerja karyawan, dimana pemberian kompensasi sangat penting bagi karyawan yang diharapkan mampu memberikan kesejahteraan 
hidup bagi karyawan tersebut, sehingga dapat memotivasi karyawan agar bekerja lebih baik lagi dan akan berdampak pada peningkatan prestasi kerja karyawan. Andrew dalam Hasibuan (2009) menyebutkan bahwa kompensasi adalah segala sesuatu yang dikonstitusikan atau dianggap sebagai suatu balas jasa atau ekuivalen.

\section{Penelitian Terdahulu}

Penelitian yang dilakukan Agustriyana, (2015) mendapatkan hasil jika karakteristik pekerjaan berpengaruh signifikan terhadap motivasi kerja. Hasil yang sama juga didapat oleh Minarsih, (2015), bahwa karakteristik pekerjaan berpengaruh signifikan terhadap motivasi kerja.

Penelitian yang dilakukan Agustriyana, (2015) mendapatkan hasil jika kompensasi berpengaruh signifikan terhadap motivasi kerja. Hasil yang sama juga didapat oleh Minarsih, (2015), bahwa kompensasi berpengaruh signifikan terhadap motivasi kerja. Semakin banyak kompensasi karyawan maka semakin meningkat motivasi kerja.

Penelitian yang dilakukan Hermawan, (2012) bahwa karakteristik pekerjaan berpengaruh signifikan terhadap kinerja pegawai. Namun hasil berbeda diungkapkan penelitian yang dilakukan Dharma, (2018) bahwa Karakteristik pekerjaan tidak berpengaruh terhadap kinerja pegawai.

Penelitian yang dilakukan Santoso, (2017) bahwa Kompensasi berpengaruh signifikan terhadap kinerja pegawai. Namun hasil berbeda diungkapkan penelitian yang dilakukan Zukrufillah, (2018) bahwa Kompensasi tidak berpengaruh terhadap kinerja pegawai.

Penelitian yang dilakukan Santoso, (2017) dan Azis, (2018) bahwa motivasi kerja berpengaruh signifikan terhadap kinerja pegawai. Hasil yang sama diungkapkan penelitian yang dilakukan Dharma, (2018) bahwa motivasi kerja berpengaruh signifikan terhadap kinerja pegawai.

\section{Perumusan Hipotesis dan Model Penelitian}

H1 : karakteristik pekerjaan berpengaruh terhadap motivasi kerja

$\mathrm{H} 2$ : kompensasi berpengaruh terhadap motivasi kerja

H3 : karakteristik pekerjaan berpengaruh terhadap kinerja pegawai

H4 : kompensasi berpengaruh terhadap kinerja pegawai

H5 : motivasi kerja berpengaruh terhadap kinerja pegawai 


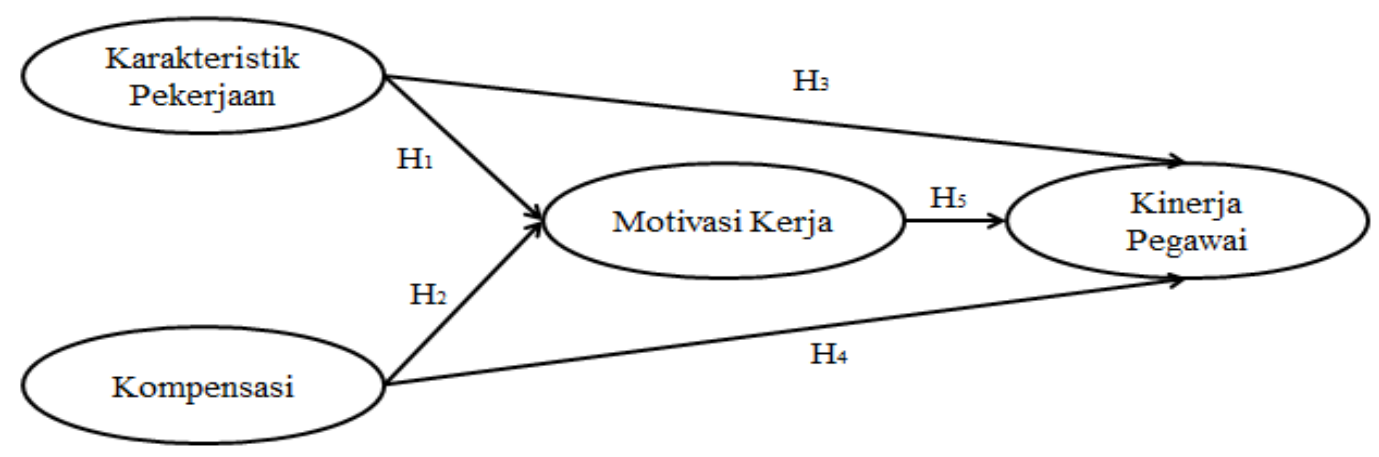

Gambar 1. Model Penelitian

\section{METODE PENELITIAN}

\section{Penentuan Populasi dan Sampel}

Populasi dalam penelitian ini adalah seluruh pegawai kelurahan non ASN di Kecamatan Pakis Aji, Jepara yang berjumlah 101 orang. Teknik pengambilan sampel menggunakan metode sensus sampling atau pengambilan sampel dengan menggunakan keseluruhan populasi. maka dalam penelitian ini metode penentuan sampel yang dipergunakan adalah sensus sampling,yang artinya keseluruhan jumlah populasi dijadikan sampel penelitian. Metode ini dipilih mengingat jumlah populasi yang relatif sedikit dan selain itu batas sampel minimal dalam penggunaan model SEM adalah 100 responden, sehingga sampel dalam penelitian ini berjumlah 101 responden yang sekiranya dapat dibilang sudah cukup mewakili.

\section{Metode Pengumpulan Data}

Metode pengumpulan data yang digunakan dalam penelitian ini berupa kuesioner. Kuesioner merupakan teknik pengumpulan data dengan cara memberi seperangkat pertanyaan tertulis kepada responden untuk dijawabnya. Kuesioner diukur dengan skala likert atau skala 1-5 yang dijabarkan dari indikator variabel penelitian.

\section{Analisis Data}

\section{Uji Validitas}

Uji validitas digunakan untuk mengukur indikator dari variabel penelitian yang dijadikan suatu pertanyaan kuesioner. Suatu kuesioner dikatakan valid jika pertanyaan pada kuesioner mampu untuk mengungkapkan sesuatu yang akan diukur oleh kuesioner tersebut (Ghozali, 2013). Pengujian validitas dilakukan dengan menggunakan uji Kaiser-Meyer-Olkin Measure of Sampling Adequacy. 


\section{Uji Reliabilitas}

Reliabilitas adalah alat ukur untuk mengukur jawaban suatu kuesioner yang merupakan indikator dari suatu variabel. Suatu kuesioner dikatakan reliabel atau handal jika jawaban seseorang terhadap pertanyaan adalah konsisten atau stabil dari waktu ke waktu. Suatu data dikatakan reliabel adalah variabel memiliki nilai Cronbach alpha 0,60 atau tidak reliabel apabila memiliki nilai Cronbach alpha lebih kecil dari 0,60 (Ghozali, 2013).

\section{Uji Normalitas Analisis Jalur}

Uji normalitas bertujuan untuk menguji apakah dalam model analisis jalur, variabel dependen dan indepedennya mempunyai distribusi normal atau tidak. Uji normalitas dilakukan dengan uji skewness dan kurtosis baik secara univariate maupun multivariate. (Ghozali, 2013).

\section{Structural Equations Modeling (SEM)}

Alat analisis dalam penelitian ini SEM (struktur equitions modeling). Model analisis jalur (SEM) yang telah dilakukan, nantinya diperoleh nilai koefisien jalur model standardized dan nilai t hitung (Ghozali, 2013). Dari hasil pengujian tersebut dapat ditulis persamaan sebagai berikut :

$Y_{1}=\alpha+\beta_{1} X_{1}+\beta_{2} X_{2}+e$

$Y_{2}=\alpha+\beta_{3} X_{1}+\beta_{4} X_{2}+\beta_{5} y_{1}+e$

\section{Pengujian Hipotesis}

Untuk menguji Hipotesis penelitian dengan uji t yaitu suatu uji untuk mengetahui signifikansi pengaruh variabel bebas secara parsial atau individual menerangkan variabel terikat. Pengujian dengan membandingkan $t$ statistik $>\mathrm{t}$ value $(1,96)$ yang berarti hipotesis diterima (Ghozali, 2013).

\section{Uji Sobel Test}

Uji sobel ini digunakan untuk mengetahui pengaruh variabel mediasi yaitu kepuasan. Menurut Baron dan Kenny (1986) dalam Ghazali (2013) suatu variabel disebut intervening jika variabel tersebut ikut mempengaruhi hubungan antara variabel independen dan variabel dependen.

\section{Kelayakan Model (Goodness of Fit Test)}

Uji Goodness of fit test digunakan untuk melakukan pengujian kemaknaan model dalam menjelaskan hubungan antar variabel sebagaimana yang dihipotesiskan. 


\section{HASIL PENELITIAN DAN PEMBAHASAN}

\section{Model Jalur}

Model analisis jalur yang telah dilakukan dengan LISREL diperoleh nilai koefisien jalur model standardized dan nilai t hitung.

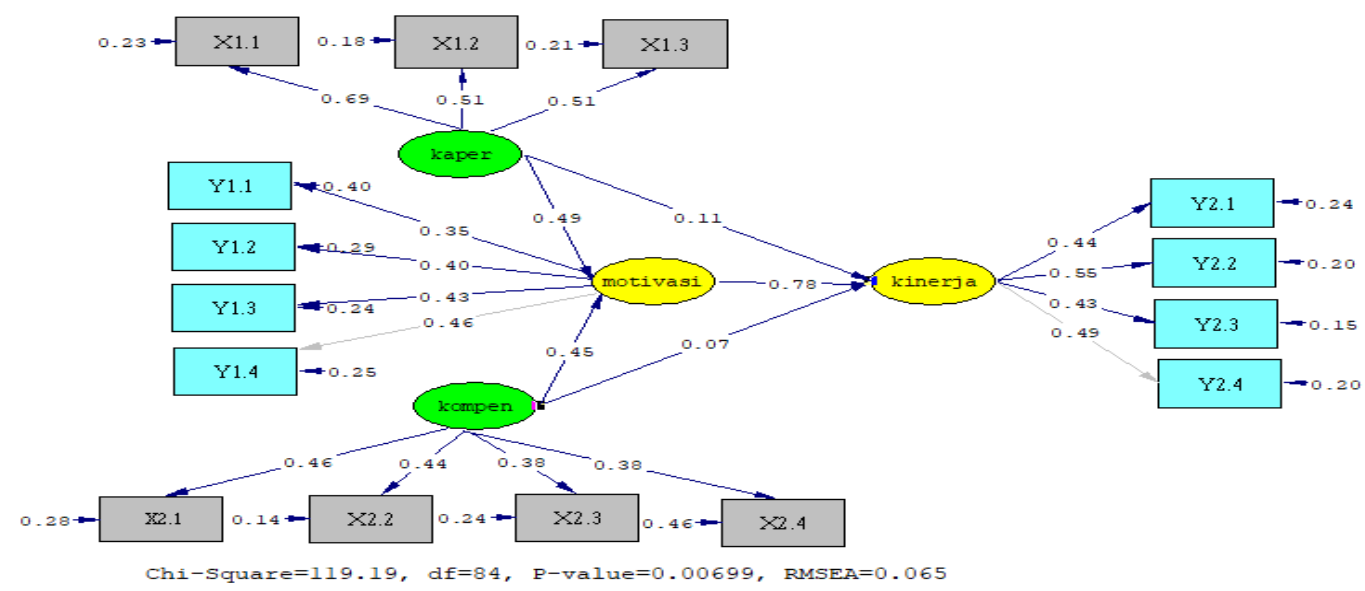

Gambar 2. Uji Signifikansi - Standardized Estimates

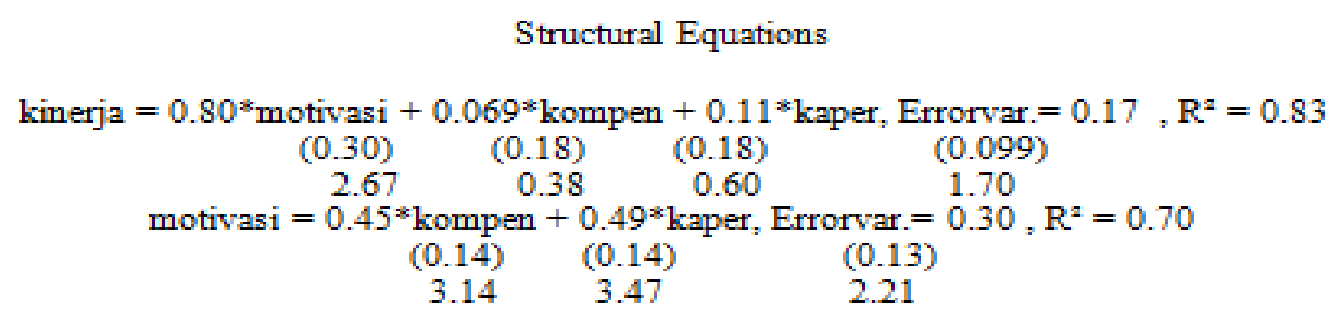

Berdasakan análisis jalur pada gambar 4.1 diperoleh semua koefisien variabel memiliki arah koefisien yang bertanda positif. Hasil ini mendukung dugaan semula bahwa Kinerja Pegawai dapat ditingkatkan melalui variabel-variabel penelitian yaitu variabel Karakteristik pekerjaan, Kompensasi, dan motivasi kerja, dengan interpretasi sebagai berikut :

1. Karakteristik pekerjaan memiliki koefisien regresi ke arah positif terhadap motivasi kerja. Hal ini dapat diartikan bahwa semakin baik Karakteristik pekerjaan, maka semakin meningkat motivasi kerja

2. Kompensasi memiliki koefisien regresi ke arah positif terhadap motivasi kerja. Hal ini dapat diartikan bahwa semakin baik kompensasi maka semakin meningkat motivasi kerja.

3. Motivasi kerja memiliki koefisien regresi ke arah positif terhadap Kinerja Pegawai. Artinya semakin baik motivasi kerja maka semakin meningkat Kinerja Pegawai. 


\section{Pengujian Hipotesis}

Untuk pengujian hipótesis untuk mengetahui pengaruh variabel bebas terhadap variabel terikat dengan membandingkan nilai t hitung yang didapat dari model jalur dengan $\mathrm{t}$ tabel sebesar 1,96 yang dapat dilihat dari model T-Value.

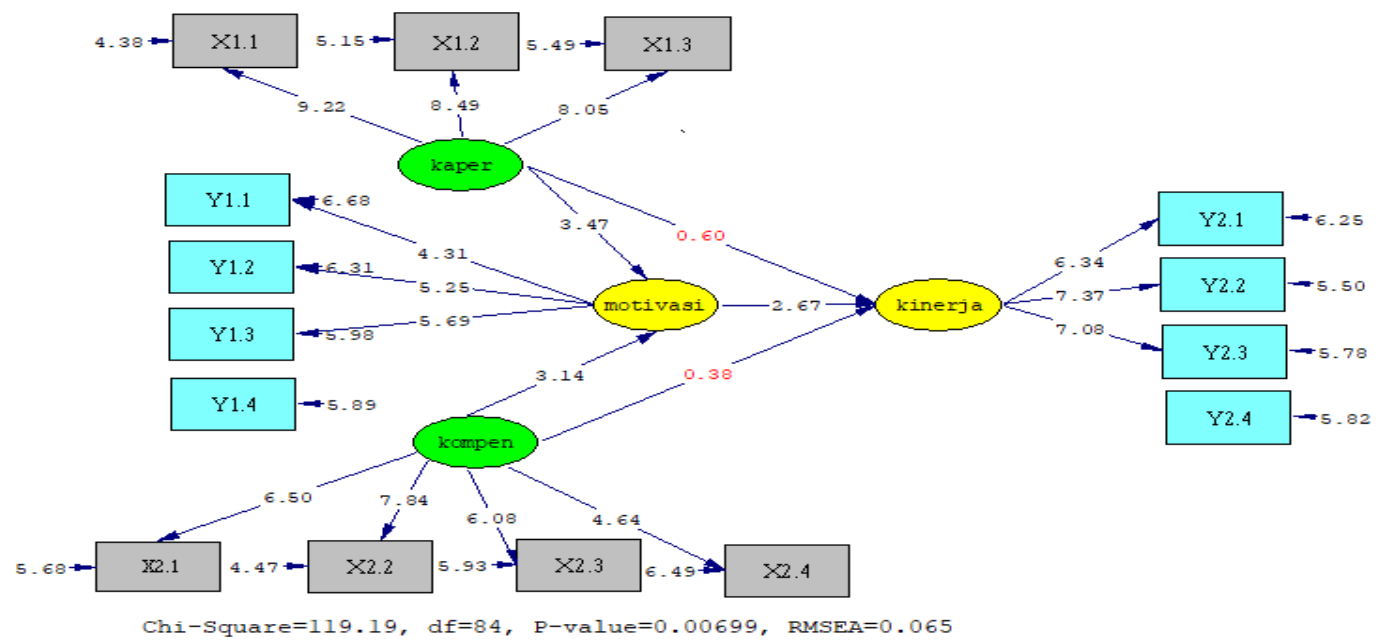

Gambar 3. Uji signifikansi - Model T-Vlue

Tabel 3. Pengujian Hipotesis

\begin{tabular}{|l|l|l|l|l|}
\hline \multicolumn{1}{|c|}{ Variabel } & \multicolumn{1}{c|}{$\begin{array}{c}\text { T } \\
\text { Value }\end{array}$} & $>$ & $\begin{array}{c}\text { T } \\
\text { Statistik }\end{array}$ & Keterangan \\
\hline Karakteristik pekerjaan $\rightarrow$ Motivasi kerja & $\mathbf{3 , 4 7}$ & $>$ & $\mathbf{1 . 9 6}$ & Signifikan \\
\hline Kompensasi $\rightarrow$ Motivasi kerja & $\mathbf{3 , 1 4}$ & $>$ & $\mathbf{1 . 9 6}$ & Signifikan \\
\hline Karakteristik pekerjaan $\rightarrow$ Kinerja Pegawai & $\mathbf{0 , 6 0}$ & $<$ & $\mathbf{1 . 9 6}$ & $\begin{array}{l}\text { Tidak } \\
\text { Signifikan }\end{array}$ \\
\hline Kompensasi $\rightarrow$ Kinerja Pegawai & $\mathbf{0 , 3 0}$ & $<$ & $\mathbf{1 . 9 6}$ & $\begin{array}{l}\text { Tidak } \\
\text { Signifikan }\end{array}$ \\
\hline Motivasi kerja $\rightarrow$ Kinerja Pegawai & $\mathbf{2 , 6 7}$ & $>$ & $\mathbf{1 . 9 6}$ & Signifikan \\
\hline
\end{tabular}

Sumber : data yang diolah, 2019

\section{Sobel Tes}

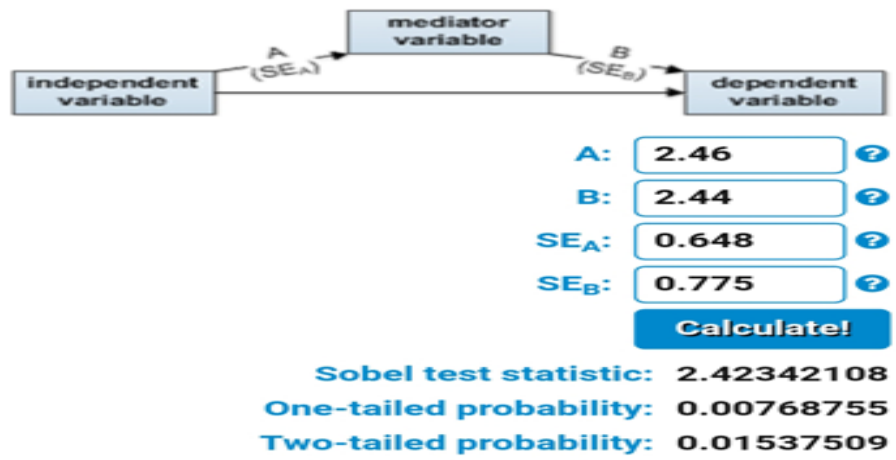

\section{Gambar 4. Hasil Uji Sobel Tes 1}


Hasil perhitungan sobel tes 1 menunjukkan nilai sobel tes statistik sebesar 2.42 lebih besar dari 1.96. Artinya variabel motivasi kerja berpengaruh signifikan dalam memediasi pengaruh antara karakteristik pekerjaan terhadap Kinerja Pegawai.

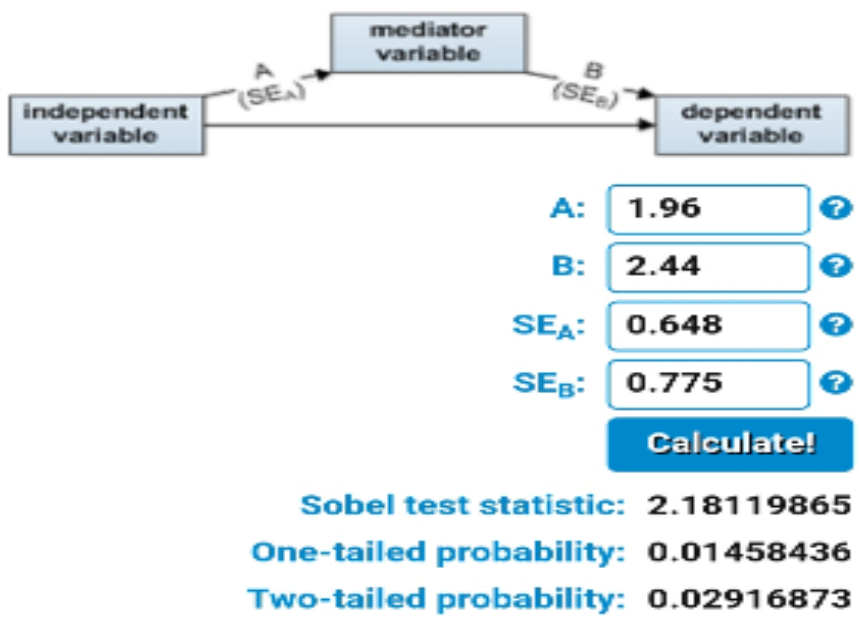

\title{
Gambar 5. Hasil Uji Sobel Tes 2
}

Hasil perhitungan sobel tes 2 menunjukkan nilai sobel tes statistik sebesar 2.18 lebih besar dari 1.96. Artinya variabel motivasi kerja berpengaruh signifikan dalam memediasi pengaruh antara kompensasi terhadap Kinerja Pegawai.

\section{Kelayakan Model (Goodness of Fit Test)}

\author{
Goodness of Fit Statistics \\ Degrees of Freedom $=84$ \\ Minimum Fit Function Chi-Square $=130.96(\mathrm{P}=0.00080)$ \\ Normal Theory Weighted Least Squares Chi-Square $=119.19(\mathrm{P}=0.0070)$ \\ Estimated Non-centrality Parameter $(\mathrm{NCP})=35.19$ \\ 90 Percent Confidence Interval for $\mathrm{NCP}=(10.23 ; 68.16)$ \\ Minimum Fit Function Value $=1.31$ \\ Population Discrepancy Function Value $(\mathrm{F} 0)=0.35$ \\ 90 Percent Confidence Interval for F0 $=(0.10 ; 0.68)$ \\ Root Mean Square Error of Approximation (RMSEA) $=0.065$ \\ 90 Percent Confidence Interval for RMSEA $=(0.035 ; 0.090)$ \\ P-Value for Test of Close Fit $($ RMSEA $<0.05)=0.18$
}

Berdasarkan hasil uji goodness of fit test didapatkan nilai chi square sebesar 130.96 dengan tingkat signifikansi $0.000<0,05$. Nilai estimasi NCP pada model sebesar 35.19 dan nilai confidence intervalnya adalah 10.23;68.16. Nilai tersebut termasuk nilai kecil sehingga dapat diartikan model berada pada katagori cukup baik atau cukup layak dijadikan sebagai model penelitian. 


\section{Pembahasan}

Berdasarkan hasil pengujian hipotesis, didapatkan hasil bahwa karakteristik pekerjaan dengan indikator ketrampilan, signifikansi tugas dan identitas tugas berpengaruh signifikan terhadap motivasi kerja. Artinya semakin baik karakteristik pekerjaan dapat meningkatkan motivasi pegawai dalam menjalankan pekerjaannya. Berdasarkan hasil dari kuesioner terbuka menunjukan banyaknya responden yang memberikan jawaban setuju pada variabel karakteristik pekerjaan, yang artinya responden memiliki ketrampilan dalam menjalankan pekerjaan, selalu mendapatkan signifikan tugas dan identitas tugas dari atasan ditempat bekerja sesuai dengan tupoksi dengan begitu pegawai akan terdorong untuk menyelesaikan pekerjaannya. Hasil penelitian ini sesuai dengan penelitian yang dilakukan Agustriyana, (2015) mendapatkan hasil jika karakteristik pekerjaan berpengaruh signifikan terhadap motivasi kerja. Hasil yang sama juga didapat oleh Minarsih, (2015), bahwa karakteristik pekerjaan berpengaruh signifikan terhadap motivasi kerja.

Didapatkan hasil bahwa kompensasi dengan indikator kecukupan gaji yang diterima, tunjangan sesuai dengan peranan, pemberian libur/ cuti yang sesuai dan asuransi yang diberikan berpengaruh signifikan terhadap motivasi kerja. Berdasarkan hasil dari kuesioner terbuka menunjukan banyaknya responden yang memberikan jawaban setuju, yang artinya responden memang merasa mendapatkan gaji sesuai dengan kebutuhan keluarga, tunjangan yang diberikan juga sesuai dengan peranan pekerjaan, dan cuti kerja sesuai ketetapan yang telah diatur sebelumnya, serta asuransi yang diberikan juga sesuai ketetapan yang telah diatur perusahaan. Hasil penelitian ini sesuai dengan penelitian yang dilakukan Agustriyana, (2015) mendapatkan hasil jika kompensasi berpengaruh signifikan terhadap motivasi kerja. Hasil yang sama juga didapat oleh Minarsih, (2015), bahwa kompensasi berpengaruh signifikan terhadap motivasi kerja. Semakin banyak kompensasi karyawan maka semakin meningkat motivasi kerja.

Didapatkan hasil bahwa karakteristik pekerjaan dengan indikator keterampilan, signifikan tugas, dan identitas tugas tidak berpengaruh terhadap kinerja pegawai. Berdasarkan kuesioner terbuka menunjukan bahwa terdapat beberapa responden yang memberikan penilaian tidak setuju, hal ini dikarenakan dengan adanya tupoksi justru mengekang pegawai sehingga tidak dapat meningkatkan ketrampilan yang dimiliki dan 
membuat signifikansi tugas dan identitas tugas menjadi monoton tanpa perkembangan. Hasil penelitian ini sesuai dengan penelitian yang dilakukan Dharma, (2018) bahwa Karakteristik pekerjaan tidak berpengaruh terhadap kinerja pegawai. Namun hasil berbeda diungkapkan penelitian yang dilakukan Hermawan, (2012) bahwa karakteristik pekerjaan berpengaruh signifikan terhadap kinerja pegawai.

Didapatkan hasil bahwa kompensasi dengan indikator kecukupan gaji yang diterima, tunjangan sesuai dengan peranan, pemberian libur/ cuti yang sesuai dan asuransi yang diberikan tidak berpengaruh terhadap kinerja pegawai. Hal ini dikarenakan pegawai bekerja sesuai dengan tupoksinya, sehingga pegawai hanya bekerja tanpa memaksakan kehendak untuk naik kompensasi, apalagi kompensasi pegawai kelurahan merupakan kebijakan dari pemerintah. Berdasarkan hasil kuesioner terbuka menunjukan bahwa terdapat responden yang memberikan penilaian tidak setuju pada variabel kompensasi dengan alasan, asuransi yang diberikan hanya termasuk golongan kelas 2, sedangkan bila terjadi resiko, pihak rumah sakit selalu meminta untuk naik kelas satu bahkan VIP, sehingga hanya sebagian saja perawatan yang bisa ditanggulangi asuransi yang diberikan. Oleh karena itu para pegawai hanya menjalankan pekerjaan seperti biasa saja dengan menerima iklhas kompensasi yang diberikan. Hasil penelitian ini sesuai dengan penelitian yang dilakukan Zukrufillah, (2018) bahwa Kompensasi tidak berpengaruh terhadap kinerja pegawai, namun hasil berbeda dengan penelitian yang dilakukan Santoso, (2017) bahwa Kompensasi berpengaruh signifikan terhadap kinerja pegawai.

Didapatkan hasil bahwa motivasi kerja dengan indikator kebutuhan penghargaan, dorongan mencapai tujuan, kebutuhan aktualisasi diri dan insentif sesuai beban kerja berpengaruh signifikan terhadap kinerja pegawai. Berdasarkan hasil dari kuesioner terbuka menunjukan banyaknya responden yang memberikan jawaban setuju, yang artinya responden mendapatkan penghargaan dan dorongan semangat dari atasan untuk menyelesaikan pekerjaan serta mendapatkan kepercayaan penuh oleh atasan untuk meningkatkan aktualisasi diri sehingga para pegawai akan termotivasi untuk meningkatkan kualitas hasil kerjanya. Hasil penelitian ini sesuai dengan penelitian yang dilakukan Santoso, (2017) Dharma, (2018) dan Azis, (2018) bahwa motivasi kerja berpengaruh signifikan terhadap kinerja pegawai. 


\section{KESIMPULAN DAN IMPLIKASI}

\section{Kesimpulan}

Dalam bab kesimpulan ini, peneliti berusaha menjawab perumusan permasalahan dan pertanyaan penelitian yang telah dibahas pada bab sebelumnya mengenai pengaruh Karakteristik pekerjaan dan Kompensasi terhadap Kinerja Pegawai melalui motivasi kerja sebagai variabel intervening, maka dapat disimpulkan bahwa :

1. Dalam menjawab perumusan permasalahan penelitian yaitu bagaimana meningkatkan kinerja pegawai melalui motivasi kerja sebagai variabel intervening dapat dilihat dari hasil uji sobel tes yang membuktikan bahwa pengaruh tidak langsung lebih tepat digunakan dari pada pengaruh langsung, atau dengan kata lain dengan adanya motivasi kerja yang baik dapat mempengaruhi karakteristik pekerjaan dan kompensasi sebagai upaya meningkatkan kinerja pegawai.

2. Dalam menjawab pertanyaan penelitian dapat dilihat dari hasil pengujian hipotesis bahwa :

1. Karakteristik pekerjaan berpengaruh signifikan terhadap motivasi kerja.

2. Kompensasi berpengaruh signifikan terhadap motivasi kerja.

3. Karakteristik pekerjaan tidak berpengaruh terhadap Kinerja Pegawai

4. Kompensasi tidak berpengaruh terhadap Kinerja Pegawai

5. Motivasi kerja berpengaruh signifikan terhadap Kinerja Pegawai.

\section{Implikasi Managerial}

Implikasi managerial ini ditujukan bagi pegawai kelurahan dikecamatan Pakis Aji agar semakin berkembang.

\section{Karakteristik pekerjaan}

Melihat deskriptive variabel karakteristik pekerjaan, nilai indeks terendah berada pada indikator signifikansi tugas. Diharapkan tupoksi tidak hanya diberikan pada pegawai terkait akan tetapi pimpinan dapat mengawasi atau memantau jalannya pekerjaan yang dilakukan pegawai, sehingga bila terjadi kemelencengan pekerjaan di luar tupoksi, pimpinan dan memberikan tindak lanjut yang sesuai. 


\section{Kompensasi}

Melihat deskriptive variabel kompensasi, nilai indeks terendah berada pada indikator asuransi yang diberikan. Diharapkan pimpinan dapat menjelaskan lebih detail tentang hak asuransi yang diterima, sehingga tidak terjadi kesalahfahaman dengan apa yang ditangkap pegawai.

3. Motivasi kerja

Melihat deskriptive variabel motivasi kerja, nilai indeks terendah berada pada indikator dorongan mencapai tujuan. Diharapkan pimpinan dapat memberikan dorongan kepada pegawai dengan cara memberikan support tentang program pendidikan yang dicanangkan pemerintah, sehingga dengan pendidikan yang lebih tinggi pola berfikir semakin terarah dan tujuan dapat dicapai.

\section{Keterbatasan Penelitian}

Penelitian ini memiliki keterbatasan penelitian yang perlu diulas, untuk pembahasan lebih lanjut pada peneliti selanjutnya. Berikut keterbatasan pada penelitian ini yaitu keterbatasan jumlah sampel yang hanya berjumlah 101 pegawai kelurahan dikecamatan Pakis Aji. Berikutnya dari 5 hipotesis yang diajukan, ternyata terdapat 2 hipotesis yang ditolak karakteristik pekerjaan tidak berpengaruh terhadap kinerja pegawai dan kompensasi tidak berpengaruh terhadap kinerja pegawai.

\section{Agenda Penelitian Mendatang}

Melihat keterbatasan penelitian, maka diharapkan penelitian mendatang diharapkan dapat menambah jumlah sampel dengan cara memperluas objek penelitian. berikutnya dapat menguji ulang variabel penelitian yang sama dengan cara lebih mempertajam indikator variabel tersebut, sehingga hasil pengujian hipotesis dapat lebih akurat. 


\section{DAFTAR PUSTAKA}

Abdillah, A.Chaidir dan Farid Wajdi. 2011. "Pengaruh Kepemimpinan, Stres Kerja, Disiplin Kerja,Dan Kompensasi Dengan Kinerja Pegawai”. Daya Saing Jurnal Ekonomi Manajemen Sumber Daya, Vol. 12, No. 1, Juni 2011, Universitas Muhammadiyah Surakarta.

Agustriyana, 2015, Analisis Faktor-Faktor Penempatan Karyawan Terhadap Motivasi kerja Karyawan di PT. Yuniko Asia Prima di Kota Bandung. Jurnal Ekonomi,Bisnis\& Entrepreneurship. Vol. 9, No. 2, Oktober 2015, 158178ISSN2443-2121

Azis, Dirham. 2018. Pengaruh Motivasi Kerja, Kompetensi, Dan Kompensasi Terhadap Kinerja Pegawai Pada Kantor Pelayanan Pajak Pratama Makassar Selatan. Jurnal Aplikasi Manajemen, Ekonomi dan Bisnis. Vol. 2, No.2, April 2018. ISSN 2541-1438; E-ISSN 2550-0783

Cushway, B dan Lodge, D. 1987. Perilaku dan Desain Organisasi. Jakarta: Gramedia, Terjemahan.

Daft, Richard L. 2002. Manajemen. Edisi Kelima Jilid Satu. Jakarta : Erlangga

Dharma, Robby, 2018. Pengaruh Lingkungan Kerja dan Karakteristik Pekerjaan dan Motivasi Terhadap Kinerja Karyawan Pada Bank Mega Syariah Cabang Padang. Majalah Ilmiah, Vol. 25, No. 1, Hal. 9-17, E-ISSN 2502-8774 P-ISSN 1412-5854.

Ferdinand, Augusty. 2014. Metode Penelitian Manajemen, UNDIP, Semarang.

Ghozali, Imam. 2014. Structural Equation Modeling, Metode Alternatif dengan Partial Least Square (PLS). Edisi 4. Semarang : Badan Penerbit Universitas Diponegoro.

Hasibuan, Malayu S.P., 2009. Manajemen : Dasar, Pengertian, dan Masalah. Edisi Revisi. Jakarta : Bumi Aksara.

Hasibuan, Malayu S.P., 2010. Organisasi dan Motivasi, Dasar Peningkatan Produktivitas, Jakarta: Bumi Aksara.

Hermawan, Hendy, 2012. Pengaruh Karakteristik Pekerjaan, Kepuasan Kerja dan Komitmen Terhadap Kinerja Karyawan PT Sebra Cipta Mandiri Malang. Jurnal Ekonomi dan Bisnis, Volume 5, Nomor 2.

Khaerul. Umam. 2010. Perilaku Organisasi. Bandung: Pustaka Setia

Leonard, Sayles dan Strauss, George. 1999. Manajemen Personalia. Jakarta : Penerbit IPPM dan PT. Pustaka Binaman Pressindo

Mathis L. Robert dan Jackson H John. 2001, Manajemen Sumber Daya Manusia, Jakarta : Buku kedua.

Minarsih, (2015) Pengaruh kompensasi, karakteristik pekerjaan, karakteristik organisasi komitmen organisasi dan Lingkungan Kerja Terhadap Motivasi kerja Di Universitas Malang. Journal of Management.1. ISSN 3443-6131. 
Ndraha, Taliziduhu. 2002. Pengantar Teori Pengembangan Sumber Daya Manusia. Rineka Cipta. Jakarta.

Padliansyah, Masjaya dan Bambang Irawan, 2014. Hubungan Karakteristik Individu Dan Keadilan Organisasional Terhadap Kinerja Pegawai Bagian Perekonomian Sekretariat Daerah Kabupaten Kutai Timur. E-Journal Administrative Reform, 2 (4) : 2659-2670, ISSN 2338-7637.

Panggabean, S., Mutiara. 2004. Manajemen Sumber Daya Manusia. Bogor: Ghalia Indonesia.

Pudjiati, dan Eka Isnianti, 2016. Pengaruh Kompetensi, Disiplin, dan Karakteristik Individu Terhadap Kinerja Dosen Universitas Balikpapan. Jurnal GeoEkonomi, Volume 07, Nomor 02, P-ISSN : 2086-1117, E-ISSN : 2503-4790.

Rivai, Veitzal., 2003, Manajemen Sumber Daya Manusia untuk Perusahaan: Dari Teori ke Praktik. Jakarta: PT. Rajagrafindo Persada.

Rivai, Veithzal \& Jauvani Ella. 2009. Manajemen Sumber Daya Manusia untuk Perusahaan. Jakarta: Raja Grafindo.

Robbins, P. Stephen dan Mary Coulter. 2012. Manajemen, diterjemahkan oleh Bob Sabran, Wibi Hardani. Erlangga: Jakarta.

Santoso, Imanuel Dwi, 2017. Pengaruh Motivasi, Kompensasi, Kesehatan dan Keselamatan Kerja Terhadap Kinerja Karyawan. Jurnal Ilmu dan Riset Manajemen, Volume 6, Nomor 12, ISSN : 2461-0593.

Setiawan, Joko, 2013. Pengaruh Karakteristik Individu dan Lingkungan Kerja Terhadap Kinerja Karyawan Pada PT.Awetama Bina Reksa. Jurnal AKMENBIS, Vol. II, No. 01, ISSN : 2302-6847, Hal. 55-70.

Siagian, Sondang P. 2002. Kepemimpinan Organisasi \& Perilaku Administrasi, Jakarta: Penerbit Gunung Agung

Slamet, 2007. Kiat Meningkatkan Kinerja, Cetakan Pertama. PT. Rineka Cipta ; Jakarta.

Greenhalgh, Leonard, 1999. "Menangani Konflik". Dalam A.Dale Timpe, (Ed.), Memimpin Manusia. Alih bahasa oleh Sofyan Cikmat. Jakarta: PT.Gramedia.

Sugito, Pudjo dan Siti Nurjannah. 2004. Analisis Pengaruh Karakteristik Individu, Pekerjaan dan Organisasi pada Kinerja Karyawan Perusahaan Daerah Air Minum Kota Malang. Jurnal Penelitian. Volume XVI. Nomor 1. Universitas Merdeka. Malang

Sugiyono. 2012. Metode Penelitian Bisnis. Cetakan Kesembilan. Penerbit CV Alpha Betha. Bandung.

Sutrisno, Edy, 2011. Manajemen Sumber Daya Manusia. Jakarta : Kencana.

Yakin, Didik Chusnul, 2013. Pengaruh Implementasi Kebijakan, Karakteristik Individu, Karakteristik Organisasi Terhadap Motivasi Kerja dan Kinerja Sekretaris Desa di Kabupaten Mojokerto. DIA, Jurnal Administrasi Publik, Vol. 11, No. 1, Hal. 129-145.

Zuchrufillah, Nur Atika, et. al., 2018. Pengaruh Promosi Jabatan dan Kompensasi Terhadap Kinerja Karyawan. e-Jurnal Riset Manajemen Prodi Manajemen. 